\title{
EFEITO DA DENSIDADE DE MUDAS POR CÉLULA E DO VOLUME DA CÉLULA NA PRODUÇÃO DE MUDAS E CULTIVO DA RÚCULA
}

\author{
Effect of seedlings density per cells and cells \\ volume on seedlings production and yield of rocket press
}

\author{
Marie Yamamoto Reghin ${ }^{1}$, Rosana Fernandes Otto ${ }^{1}$, Jhony Van Der Vinne ${ }^{2}$
}

\section{RESUMO}

O experimento foi conduzido em Ponta Grossa (PR) com o objetivo de avaliar o efeito da densidade de mudas por célula em diferentes bandejas na produção de mudas e no cultivo da rúcula. $\mathrm{O}$ delineamento experimental foi o de blocos casualizados com quatro repetições; os tratamentos foram distribuídos conforme esquema fatorial 4 x 2, sendo densidades de mudas por célula (uma, duas, três e quatro), e dois tipos de bandejas de poliestireno expandido ( 200 e 288 células). A semeadura foi realizada em 28/03/2003, com sementes da cultivar Cultivada, em células preenchidas com o substrato Plantmax, sob cultivo protegido. Antes do transplante, avaliaram-se as características de número de folhas definitivas, comprimento da parte aérea e da raiz, matéria fresca e seca da parte aérea e da raiz. O transplante foi realizado aos 17 dias da semeadura, em parcelas com 40 plantas dispostas no espaçamento 0,20 x $0,10 \mathrm{~m}$. Na colheita, aos 20 dias do transplante, foram avaliadas as características de comprimento da parte aérea, número de folhas, matéria fresca e seca por planta. No estádio de mudas, observou-se efeito significativo de interação para algumas características avaliadas. O volume da célula foi um fator importante na produção de mudas e dependente da densidade. A melhor qualidade de muda foi proveniente de bandejas com 200 células $\left(16 \mathrm{~cm}^{3}\right)$, quando comparada com as de 288 células $\left(12 \mathrm{~cm}^{3}\right)$. À medida que houve aumento da densidade de mudas por célula, observou-se maior efeito de competição, principalmente nas bandejas com 288 células. No entanto, o comportamento diferenciado das mudas provenientes das bandejas de 200 e 288 células não se manifestou durante o cultivo. Na época de colheita, somente a característica de comprimento da parte aérea diferiu estatisticamente, sendo superior nas plantas provenientes da bandeja com 200 células. Por outro lado, a densidade de mudas promoveu respostas diferentes na produção da rúcula. Houve diminuição no comprimento da parte aérea, número de folhas, peso da matéria fresca e seca produzida por planta, em resposta à pressão de competição promovida pelo aumento da densidade. Considerando o rendimento de matéria fresca, a densidade contribuiu diretamente para o incremento dessa característica. Observou-se a média de $1,4 \mathrm{~kg} \mathrm{~m}^{-2}$, quando se usou a densidade de uma muda e de $6,4 \mathrm{~kg} \mathrm{~m}^{-2}$ com quatro mudas. Para os dois tipos de bandejas, à medida que houve aumento da densidade de mudas, houve resposta linear crescente na matéria fresca por área. Como a forma de comercialização predominante para a rúcula é em maços, o rendimento promovido pela densidade de quatro mudas, tanto na bandeja de 200 como na de 288 células, apresentou-se como a alternativa mais adequada.

Termos para indexação: Eruca sativa L., produção de mudas, densidade de mudas, tamanho da célula.

\section{ABSTRACT}

The experiment was realized in Ponta Grossa (PR) aiming at avaluating seedlings density/cells using different trays and its effects on seedlings production and yield of rocket press. The experimental design was a randomised blocks with four replications; the treatments followed a factorial arrangement 4 × 2, being 1,2, 3 and 4 seedlings/cell on trays with 200 and 288 cells. Seeds were sowed on 28/03/2003, with the cultivar Cultivada on trays with commercial substrate Plantmax under protected cultivation. Before seedlings transplanting it was avaluated the characteristics of leaves number, lenght of upper part and root, fresh and dry weight of up ground material and root. The seedlings transplanting was carried out through with seventeen days in plots containing 40 plants in $0,20 \times 0,10 \mathrm{~m}$ arrangement. At harvesting, 20 days of the seedlings transplanting, it was avaluated the following characteristics: lenght of upper part, leaves number, fresh and dry weight of up ground material. On the seedlings stage it was observed a significative effect of the interaction. The cell size was an important factor on seedlings production and it depended also on seedlings densities/cell. The best seedlings quality was obtained using trays with 200 cells, compared to 288 cells. Increasing the seedlings density/cell it was observed higher effect of seedlings competition, mainly on

(Recebido para publicação em 28 de julho de 2003 e aprovado em 3 de setembro de 2003)

\footnotetext{
1. Doutoras, Professoras Adjunto de Olericultura. Departamento de Fototecnia e Fitossanidade. Universidade Estadual de Ponta Grossa, Av. Carlos Cavalcanti, 4748 - Ponta Grossa, PR. Campus de Uvaranas.

2. Bolsista de IC/CNPq, acadêmico do $5^{\circ}$ ano do curso de Agronomia. Universidade Estadual de Ponta Grossa, PR. Campus de Uvaranas.
} 
trays of 288 cells on the characteristics of leaves number, fresh weight of up ground material and lenght of upper part and root. However these differences were diluted during plants development on the field, being at the harvesting only the characteristic of leaves number still superior on trays of 200 cells (volume of $16 \mathrm{~cm}^{3}$ ) compared to 288 cells $\left(12 \mathrm{~cm}^{3}\right)$. On the other hand the seedlings density/cell promoted yield response on rocket press. It was observed linear response on yield. It was observed decreasing on lenght of upper part, leaves number, fresh and dry weight of up ground material, in response of competition pressure among plants promoted by density increasing. However it was observed linear increment on yield/area with the increasing of the seedlings/density. The increment on fresh weight was significative considering yield average of $1,4 \mathrm{~kg} \mathrm{~m} \mathrm{~m}^{-2} \mathrm{on}$ density of single seedling and $6,4 \mathrm{~kg} \mathrm{~m}^{-2}$ when it was used four seedlings/cell. It was observed that when density was increased, higher was the yield on fresh weight to both trays. Considering the commercialization of rocket press mainly on bunch, it seems more interesting a higher density with four seedlings, on trays with 200 or 288 cells.

Index terms: Eruca sativa L., seedlings production, seedlings densitiy, cell size.

\section{INTRODUÇÃO}

Na olericultura, são observadas mudanças rápidas, em função do cultivo intensivo que as hortaliças imprimem no setor, exigindo cada vez mais o aprimoramento de técnicas, para obtenção de produtos de melhor qualidade. Modificações importantes nos sistemas de produção de hortaliças, nos últimos anos, vêm sendo feitas na produção de mudas. Essas são produzidas de formas diversas e a tendência é uma tecnificação cada vez maior, sempre procurando aprimorar a qualidade do produto.

A produção comercial de mudas de hortaliças utiliza basicamente ambiente protegido, irrigação, substrato, bandeja, entre outros, os quais, associados, podem determinar o prazo e aumentar a economia na produção.

A utilização de bandejas de poliestireno expandido tem se mostrado eficiente na produção, condução, transporte e plantios das mudas de hortaliças para o local definitivo, já que as bandejas são leves, de fácil manuseio, comportando um número muito grande de mudas, ocupando uma área mínima e permitindo o transplante de mudas com torrão (MINAMI,1995).

As funções principais do recipiente ou do contêiner para a produção de mudas são: proporcionar um meio para suportar e nutrir as plantas; proteger as raízes de danos mecânicos e dissecação; dar uma conformação vantajosa para as raízes; maximizar a sobrevivência no campo e o crescimento inicial, pois o sistema radicular não é danificado e permanece em contato íntimo com o substrato (TAVEIRA, 1996).

O tamanho da célula influencia as respostas de crescimento e desenvolvimento das mudas. Conforme Latimer (1991), o tamanho do recipiente e o tipo de substrato a serem utilizados são fatores importantes que influenciam diretamente o desenvolvimento e a arquite- tura do sistema radicular. Fisher e Benson (1984), estudando a influência de diferentes fatores na formação de mudas de aspargo, verificaram que células com formato cilíndrico produziram mudas com maior peso da matéria seca da parte aérea, peso da matéria seca da planta e número de ramificação por planta. Barnabé et al. (1994) estudaram três tipos de bandejas de isopor, com 128, 200 e 288 células, na produção de mudas de pimentão da cultivar Myr. Os autores concluíram que o peso da matéria fresca e seca da parte aérea e radicular das mudas produzidas na bandeja de 128 células não diferiram significativamente da bandeja de 200 células; entretanto, as duas apresentaram valores significativamente diferentes da bandeja de 288 células. Em berinjela, Barnabé et al. (1994) estudaram a influência de três diferentes tipos de bandejas de isopor com 128, 200 e 288 células no desenvolvimento e qualidade das mudas, concluindo que a bandeja de 128 células produziu mudas com valores de peso da matéria fresca e seca estatisticamente superiores aos das demais bandejas. Os autores concluíram também que as mudas produzidas em bandejas de 128 células são de melhor qualidade. Barros (1997) observou que para o tomate e pepino, o uso de recipientes de maior dimensão propiciaram os maiores valores para todos os parâmetros avaliados. Modolo e Tessarioli Neto (1998) observaram em quiabo que as mudas produzidas na bandeja de maior volume apresentaram os melhores resultados com relação ao seu desenvolvimento para todos os parâmetros estudados. Em beterraba, Guimarães et al. (2002) usaram bandejas com diferentes tamanhos de células na produção de mudas e na produtividade da cultura. Observaram que os diferentes métodos de produção de mudas não influenciaram na produtividade da cultura, porém aumentaram o ciclo, quando comparado à semeadura direta. Com a rúcula, Santos et al. (2002) observaram o comportamento em mudas produzidas nas bandejas de 128 e 242 
células, contendo duas, três e quatro plantas/célula, comparados com a semeadura direta. Pelos resultados demonstrou-se não haver diferença significativa entre os tratamentos, sendo a semeadura direta o mais indicado para essa cultura.

A rúcula (Eruca sativa L.) é uma hortaliça herbácea anual, baixa, possuindo normalmente altura de 15 a $20 \mathrm{~cm}$. As sementes são muito pequenas, possuindo em um grama cerca de 650 sementes. Trata-se de uma folhosa com crescente incremento de consumo nos últimos anos, com quantidade mensal de 16.029 dúzias de maços de $6 \mathrm{~kg}$ comercializados no CEAGESP, entre 1995 - 1999 (CAMARGO FILHO e MAZZEI, 2001).

Para o seu cultivo, Minami e Tessarioli Neto (1998) recomendam um preparo bem feito do canteiro, em razão de as sementes serem pequenas, com semeadura na quantidade de 0,2 a 0,3 g por metro linear e, após a emergência, realizar o desbaste do excesso de plantas, se necessário. Filgueira (2000) ressalta que a semente é semeada diretamente em canteiro definitivo, em sulcos longitudinais distanciados $20-30 \mathrm{~cm}$, deixando-se as plantas espaçadas de $5 \mathrm{~cm}$, após o desbaste.

Por sua vez, com a semeadura direta, vários fatores estão envolvidos, de forma que, muitas vezes, é difícil obter um estande uniforme, principalmente se tratando de sementes pequenas como as da rúcula.

Para o produtor interessado na colheita de safras durante o ano todo, é necessária a otimização da produção e a obtenção de alto rendimento, de produto uniforme e de alta qualidade. Nesse tipo de cultivo, é altamente prejudicial contar com falhas ou desuniformidade no estande. O cultivo com mudas transplantadas é uma das alternativas para contornar essa ocorrência. No entanto, observou-se escassez de informações sobre produção de mudas e comportamento posterior no cultivo da rúcula.

Com o presente trabalho teve-se como objetivo avaliar densidades crescentes de mudas em células de tamanhos diferentes, provenientes de bandejas de 200 e 288 células e seus efeitos na produção de mudas e no cultivo posterior da rúcula.

\section{MATERIAL E MÉTODOS}

O experimento foi conduzido na Universidade Estadual de Ponta Grossa, em Ponta Grossa (PR), localizada a $880 \mathrm{~m}$ de altitude, em solo do tipo CAMBISSOLO HÁPLICO Tb Distrófico, de textura argilosa. O delineamento experimental foi o de blocos casualizados, com quatro repetições; os tratamentos foram distribuídos segundo esquema fatorial 4 × 2 , sendo uma, duas, três e quatro mudas por célula, em dois tipos de bandeja, com 200 (volume de $16 \mathrm{~cm}^{3}$ ) e 288 células (volume de $12 \mathrm{~cm}^{3}$ ). A fase de mudas foi conduzida sob cultivo protegido em estrutura metálica de arcos, coberta com polietileno transparente de 120 micras, durante o período de 28/03/2003 a 14/04/2003. Foram utilizadas 8 bandejas de poliestireno expandido, sendo quatro de 200 e quatro de 288 células, preenchidas com o subtrato plantmax, dispostas numa bancada a um metro de altura e distribuídas de forma casualizada. Tanto na bandeja de 200 como na de 288 células foram colocadas as quantidades de 1, 2, 3 ou 4 sementes por célula a $0,5 \mathrm{~cm}$ de profundidade, usando-se a cultivar Cultivada (Agroflora). Aos 17 dias da semeadura, foram avaliadas numa amostra de 20 plantas por tratamento, as características de comprimento da parte aérea, número de folhas, comprimento da raiz (após destacá-la da parte aérea, lavagem em água corrente sob peneira para retirada do substrato) matéria fresca e seca da parte aérea e da raiz. Nas células com mais de uma muda, cada uma delas foi avaliada individualmente e, após, feita a média para constituir a avaliação daquele tratamento. No campo, a área do experimento foi preparada e adubada com a fórmula 2 - 20 - 10, na quantidade $100 \mathrm{~g} \mathrm{~m}^{-2}$. As parcelas foram compostas de 40 plantas, em quatro fileiras arranjadas no espaçamento $0,20 \mathrm{x}$ 0,10 m. Usou-se irrigação por aspersão. Aos 13 dias do transplante, fez-se uma adubação nitrogenada em cobertura com uréia na quantidade de $10 \mathrm{~g}$ por metro. Aos 28 dias do transplante, foi realizada a colheita, quando foram avaliados: comprimento da parte aérea, número de folhas, matéria fresca e seca da parte aérea. A matéria seca foi obtida em estufa de ventilação forçada a $60^{\circ} \mathrm{C}$, até atingir peso constante. Os dados obtidos foram submetidos à análise de variância e ao teste de Tukey para o fatorial. E os dados de densidade na colheita, à regressão polinomial e ao teste $\mathrm{F}$.

\section{RESULTADOS E DISCUSSÃ̃}

\section{Produção de mudas}

Houve interação significativa entre a densidade de mudas por célula e o tamanho de células para as características de número de folhas, comprimento da parte aérea, comprimento da raiz, matéria fresca e seca da parte aérea e matéria fresca da raiz (Tabelas 1 e 2). Somente na característica de matéria seca da raiz, não foi observada interação significativa (Tabela 2).

$\mathrm{O}$ desenvolvimento das mudas foi rápido, considerando que, no sexto dia da semeadura, todas as plân- 
tulas haviam emergido, e aos dezessete dias, a maioria dos tratamentos já apresentava quatro folhas definitivas, quando foi realizada a avaliação. Houve efeito significativo do tamanho da célula para todas as características, apresentando valores superiores, de forma geral, quando provenientes das bandejas de 200 células, com $16 \mathrm{~cm}^{3}$ de volume, enquanto as de 288 células possuem $12 \mathrm{~cm}^{3}$.

O tipo de bandeja usado não teve influência no número de folhas para a maioria das densidades testadas. Somente com a maior densidade de mudas (quatro), observou-se diferença significativa, ocorrendo superioridade da bandeja de 200 células, quando comparada com a de 288. Comparando as densidades na bandeja com 200 células, não foi verificada influência significativa desse fator na característica número de folhas. No entanto, na bandeja com 288 células, observou-se um maior número de folhas na densidade de uma muda por célula e essa apresentou diferença significativa quando comparada com três e quatro mudas por célula, com valores menores, resultantes provavelmente da maior competição ocorrida entre as mudas. À medida que ocorreu aumento da densidade, houve diminuição do número de folhas. Sob efeito de competição, o desenvolvimento foi mais atrasado, pois com densidade de três e quatro mudas por célula, essas sequer chegaram a atingir quatro folhas definitivas na época de avaliação.

Para quaisquer das densidades avaliadas, o volume maior da célula na bandeja de 200 propiciou maior desenvolvimento da parte aérea, o que pode ser observado pela característica de comprimento da parte aérea (Tabela 1), que diferiu significativamente da bandeja de 288 células. Dentro de cada tipo de bandeja, o comprimento da parte aérea não diferiu significativamente quando se compararam uma, duas ou três mudas por célula. Somente na densidade de quatro mudas por célula, a parte aérea apresentou menor desenvolvimento. Para a bandeja de 288 células, a densidade foi limitante para o desenvolvimento da parte aérea a partir de 2 mudas por célula.

O tipo de bandeja usado também teve influência sobre a produção de matéria fresca da parte aérea (Tabela 1). Na densidade de uma muda por célula, o peso da matéria fresca obtida apresentou uma superioridade de $70 \mathrm{mg}$ a favor da bandeja de 200, quando comparada com a de 288 células. Quando submetida à competição, ou seja, aumentando para 2 mudas por célula, o peso observado foi de $89,64 \mathrm{mg}$ a mais para a bandeja de 200 células. Já para as densidades de 3 e 4 mudas por célula, observou-se diferença de 48,57 mg e 37,55 mg a mais, respectivamente, na bandeja de 200 células. O volume maior da célula na bandeja de 200 propiciou um melhor desenvolvimento das mudas, enquanto na bandeja de 288, o efeito competitivo foi maior pelos fatores de crescimento, refletindo em mudas com atraso no desenvolvimento e com menor acúmulo de matéria fresca. Esses resultados estão de acordo com os encontrados na produção de mudas de outras culturas (BARNABÉ et al.,1994; BARROS, 1997; MODOLO e TESSARIOLI NETO, 1998). Quanto às densidades nos

TABELA 1 - Número de folhas, comprimento da parte aérea $(\mathrm{cm})$, matéria fresca e seca da parte aérea $(\mathrm{g})$ de mudas de rúcula, em função da densidade de mudas por célula e tipos de bandeja. UEPG, Ponta Grossa (PR),2003.

\begin{tabular}{|c|c|c|c|c|c|c|c|c|}
\hline \multirow{2}{*}{$\begin{array}{c}\text { Dens. de } \\
\text { mudas por } \\
\text { célula }\end{array}$} & \multicolumn{2}{|c|}{ Número de folhas } & \multicolumn{2}{|c|}{$\begin{array}{l}\text { Comprimento da } \\
\text { parte aérea }(\mathrm{cm})\end{array}$} & \multicolumn{2}{|c|}{$\begin{array}{l}\text { Matéria fresca da } \\
\text { parte aérea }(\mathrm{mg})\end{array}$} & \multicolumn{2}{|c|}{$\begin{array}{l}\text { Matéria seca da } \\
\text { parte aérea }(\mathrm{mg})\end{array}$} \\
\hline & $\begin{array}{l}200 \\
\text { células }\end{array}$ & $\begin{array}{l}288 \\
\text { células }\end{array}$ & $\begin{array}{l}200 \\
\text { células }\end{array}$ & $\begin{array}{l}288 \\
\text { células }\end{array}$ & $\begin{array}{c}200 \\
\text { células }\end{array}$ & $\begin{array}{c}288 \\
\text { células }\end{array}$ & $\begin{array}{c}200 \\
\text { células }\end{array}$ & $\begin{array}{c}288 \\
\text { células }\end{array}$ \\
\hline 1 & $4,23 \mathrm{~A} a *$ & $4,14 \mathrm{~A} \mathrm{a}$ & $6,46 \mathrm{~A} \mathrm{a}$ & $6,13 \mathrm{~B}$ a & $280,36 \mathrm{~A}$ a & 210,36 B a & $27,13 \mathrm{~A} \mathrm{a}$ & $19,63 \mathrm{~B}$ a \\
\hline 2 & $4,18 \mathrm{~A} \mathrm{a}$ & 4,09 Aab & $6,08 \mathrm{~A} \mathrm{a}$ & $5,07 \mathrm{~B} \mathrm{~b}$ & $228,21 \mathrm{~A} \mathrm{~b}$ & $138,57 \mathrm{~B} \mathrm{~b}$ & $24,10 \mathrm{~A} \mathrm{~b}$ & $12,68 \mathrm{~B} \mathrm{~b}$ \\
\hline 3 & $4,03 \mathrm{~A} \mathrm{a}$ & $3,91 \mathrm{~A} \mathrm{~b}$ & $6,27 \mathrm{~A} \mathrm{a}$ & $5,20 \mathrm{~B} \mathrm{~b}$ & $172,50 \mathrm{~A} \mathrm{c}$ & $123,93 \mathrm{~B} \mathrm{bc}$ & $19,65 \mathrm{~A} \mathrm{c}$ & $11,68 \mathrm{~B} \mathrm{~b}$ \\
\hline 4 & $4,05 \mathrm{~A} \mathrm{a}$ & $3,76 \mathrm{~B} \mathrm{~b}$ & $5,65 \mathrm{~A} \mathrm{~b}$ & $5,22 \mathrm{~B} \mathrm{~b}$ & $145,71 \mathrm{Ad}$ & 108,16 B c & $16,00 \mathrm{~A} \mathrm{~d}$ & $11,90 \mathrm{~B} \mathrm{~b}$ \\
\hline C.V. $(\%)$ & \multicolumn{2}{|c|}{2,32} & \multicolumn{2}{|c|}{3,19} & \multicolumn{2}{|c|}{6,55} & \multicolumn{2}{|c|}{8,07} \\
\hline
\end{tabular}

\footnotetext{
* Médias seguidas da mesma letra, maiúscula na linha e minúscula na coluna, não diferem estatisticamente
} entre si pelo teste de Tukey a $5 \%$ de probabilidade.

Ciênc. agrotec., Lavras, v. 28, n. 2, p. 287-295, mar./abr., 2004 
dois tipos de bandejas, à medida que houve aumento da densidade de mudas, observou-se diminuição do peso da matéria fresca. Esses mesmos comportamentos foram observados para a característica de matéria seca da parte aérea (Tabela 1).

O comprimento da raiz (Tabela 2), igualmente, foi uma característica que dependeu do tamanho da célula e da densidade de mudas por célula. Os maiores valores foram observados na bandeja com 200 células, quando comparados com as de 288 células. O maior volume disponível da célula propiciou taxa de crescimento mais expressivo das raízes, o que refletiu, conseqüentemente, no maior desenvolvimento da parte aérea.

Quanto às densidades, houve efeito notório sobre o comprimento da raiz, de forma que, aumentando a densidade de mudas, houve diminuição no comprimento da raiz, comportamento esse observado nos dois tipos de bandejas (Tabela 2). Na matéria fresca da raiz, o comportamento foi similar ao da parte aérea. Entre os tipos de bandejas, a de 200 células foi superior à de 288 células, com maior peso em qualquer densidade. Comparando as densidades de mudas na bandeja com 200 células, à medida que houve aumento do número de mudas, houve diminuição do peso. Na de 288 células, a variação na densidade não promoveu diferença significativa.

Na matéria seca da raiz, houve efeito significativo dos fatores de forma isolada (Tabela 2), de modo que o peso foi superior nas bandejas de 200 células, quando comparado às de 288 células. O peso foi maior com uma muda por célula, diferindo significativamente das demais densidades.

O volume maior da célula nas bandejas de 200 influenciou as respostas de crescimento das mudas de rúcula, ratificando os resultados obtidos em outras hortaliças por Latimer (1991), Barnabé et al. (1994), Barros, (1997) e Modolo e Tessarioli Neto (1998).

Para as características avaliadas, as mudas de melhor qualidade foram provenientes das bandejas com maior volume de célula $\left(16 \mathrm{~cm}^{3}\right)$ e menor densidade de planta (uma muda por célula).

\section{Cultivo da rúcula}

A colheita da rúcula foi realizada aos 28 dias após o transplante, obtendo-se plantas com desenvolvimento uniforme e sem ocorrência de falhas no estande.

Não houve interação significativa para as características avaliadas na colheita (Tabela 3). As diferenças observadas foram provenientes dos fatores de forma isolada. $\mathrm{O}$ volume maior das células na bandeja de 200 promoveu diferença significativa apenas no comprimento da parte aérea. Nas demais características, apesar de os valores superiores serem sempre oriundos da bandeja de 200, não foi observada significância estatística. Esses resultados demonstram que as diferenças observadas no estádio de mudas provenientes da bandeja

TABELA 2 - Matéria fresca $(\mathrm{g})$, comprimento $(\mathrm{cm})$ e matéria seca $(\mathrm{g})$ da raíz de mudas de rúcula em função do número de mudas por célula e tipos de bandeja. UEPG, Ponta Grossa (PR),2003.

\begin{tabular}{|c|c|c|c|c|c|c|c|}
\hline \multirow{2}{*}{$\begin{array}{l}\text { Número de } \\
\text { mudas }\end{array}$} & \multicolumn{2}{|c|}{$\begin{array}{l}\text { Matéria fresca da raiz } \\
\qquad(\mathrm{mg})\end{array}$} & \multicolumn{2}{|c|}{$\begin{array}{l}\text { Comprimento da raiz } \\
(\mathbf{c m})\end{array}$} & \multicolumn{3}{|c|}{$\begin{array}{c}\text { Matéria seca da raiz } \\
(\mathbf{m g})\end{array}$} \\
\hline & 200 células & 288 células & 200 células & 288 células & 200 células & 288 células & Média \\
\hline 1 & $126,85 \mathrm{~A} \mathrm{a}^{*}$ & $22,85 \mathrm{~B} \mathrm{a}$ & $8,91 \mathrm{~A} \mathrm{a}$ & $6,68 \mathrm{~B} \mathrm{a}$ & 10,03 & 5,70 & $7,87 \mathrm{a}$ \\
\hline 2 & 89,69 A b & $37,14 \mathrm{~B} \mathrm{a}$ & $4,22 \mathrm{Ab}$ & $3,27 \mathrm{~B} \mathrm{~b}$ & 6,60 & 3,95 & $5,28 \mathrm{~b}$ \\
\hline 3 & 46,55 A c & $22,05 \mathrm{~B} \mathrm{a}$ & $2,38 \mathrm{Ac}$ & $1,98 \mathrm{~B} \mathrm{c}$ & 6,30 & 3,43 & $4,87 \mathrm{~b}$ \\
\hline 4 & 46,25 A c & $18,66 \mathrm{~B} \mathrm{a}$ & $1,97 \mathrm{Ad}$ & $1,57 \mathrm{~B} \mathrm{~d}$ & 5,30 & 3,05 & $4,18 \mathrm{~b}$ \\
\hline Média & & & & & $7,06 \mathrm{~A}$ & $4,03 \mathrm{~B}$ & \\
\hline C.V. (\%) & \multicolumn{2}{|c|}{23,37} & \multicolumn{2}{|c|}{4,67} & \multicolumn{3}{|c|}{22,61} \\
\hline
\end{tabular}

\footnotetext{
* Médias seguidas da mesma letra, maiúscula na linha e minúscula na coluna, não diferem estatisticamente
} entre si pelo teste de Tukey a $5 \%$ de probabilidade. 
de 200 células foram diluídas durante o desenvolvimento das plantas no campo. Portanto, as mudas menores, provenientes da bandeja de 288 células, quando transplantadas estabeleceram-se e desenvolveram-se similarmente às de 200 células no campo, obtendo-se na colheita plantas com qualidade semelhante. Trata-se de um resultado importante; no entanto, não há como ser comparado com outros relatos, porque a totalidade dos trabalhos mencionados (FISHER e BENSON,1984; LATIMER, 1991; BARNABÉ et al., 1994; BARROS 1997; MODOLO e TESSARIOLI NETO, 1998) avaliou as características como produção de mudas, não sendo analisado o efeito posterior no cultivo. Por sua vez, a densidade de mudas por célula promoveu respostas produtivas significativas no cultivo da rúcula. Para todas as características avaliadas (comprimento da parte aérea, número de folhas, matéria fresca e seca por planta), houve resposta linear decrescente tanto nas bandejas de 200 células, como nas de 288 células (Figuras 1 a 2). À medida que ocorreu aumento da densidade de mudas por célula, houve diminuição da altura, número de folhas, matéria fresca e seca por planta. Dessa forma, embora o transplante tenha ocorrido no espaçamento entre plantas de $0,10 \mathrm{~m}$, relativamente amplo, observou-se que o aumento de uma para duas mudas promoveu efeito mais evidente de competição entre as plantas, ocorrendo decréscimo nas características avaliadas. Por outro lado, considerando o rendimento por área (Figura 3), a densidade foi o fator que contribuiu diretamente para o incremento desse rendimento. A contribuição foi altamente significativa ao se observar que a média de rendimento aumentou de $1,4 \mathrm{~kg} \mathrm{~m}^{-2}$ na densidade de uma muda por célula para $6,4 \mathrm{~kg} \mathrm{~m}^{-2}$ na densidade de quatro mudas. Como a forma de comercialização que predomina para a rúcula é em maços, o rendimento promovido pela maior densidade torna esse sistema mais interessante do ponto de vista da produção. Para os dois tipos de bandejas, à medida que houve aumento da densidade de mudas, houve aumento linear crescente na matéria fresca/área. Em média, a cultivar Cultivada apresentou $23,4 \mathrm{~cm}$ de comprimento da parte aérea, 12,8 folhas e $18,3 \mathrm{~g}$ de peso médio da matéria fresca. Esses valores conferiram à planta característica de alto vigor vegetativo. Minami e Tessarioli Neto (1998) citam que na fase da colheita as folhas deverão estar com 15 a $20 \mathrm{~cm}$ de comprimento. Nesse contexto, é recomendável o cultivo transplantado de rúcula, com a produção de mudas tanto em bandejas de 200 como de 288 células, usando a densidade de quatro mudas por célula.

TABELA 3 - Comprimento da parte aérea $(\mathrm{cm})$, número de folhas, matéria fresca e seca $(\mathrm{g})$ e rendimento em matéria fresca $\left(\mathrm{kg} \mathrm{m}^{-2}\right)$ obtidos na colheita, em função do tipo de muda usado no cultivo da rúcula. UEPG, Ponta Grossa (PR), 2003.

\begin{tabular}{cccccc}
\hline $\begin{array}{c}\mathbf{N}^{\mathbf{0}} \text { de células } \\
\text { por bandeja }\end{array}$ & Comp. da PA & $\mathbf{N}^{\circ}$ de folhas & Matéria fresca & Matéria seca & Rendim. em MF \\
\hline 200 & $24,35 \mathrm{a}^{*}$ & $13,12 \mathrm{a}$ & $19,23 \mathrm{a}$ & $1,71 \mathrm{a}$ & $4,16 \mathrm{a}$ \\
288 & $22,42 \mathrm{~b}$ & $12,51 \mathrm{a}$ & $17,39 \mathrm{a}$ & $1,53 \mathrm{a}$ & $3,91 \mathrm{a}$ \\
\hline C.V. $(\%)$ & 9,46 & 8,31 & 27,71 & 22,53 & 22,32 \\
\hline
\end{tabular}

* Médias seguidas da mesma letra na coluna não diferem estatisticamente entre si pelo teste de Tukey a $5 \%$ de probabilidade. 


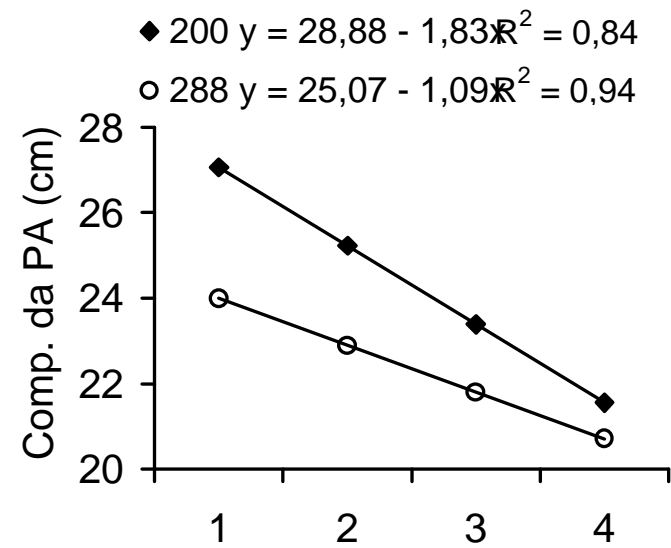

A

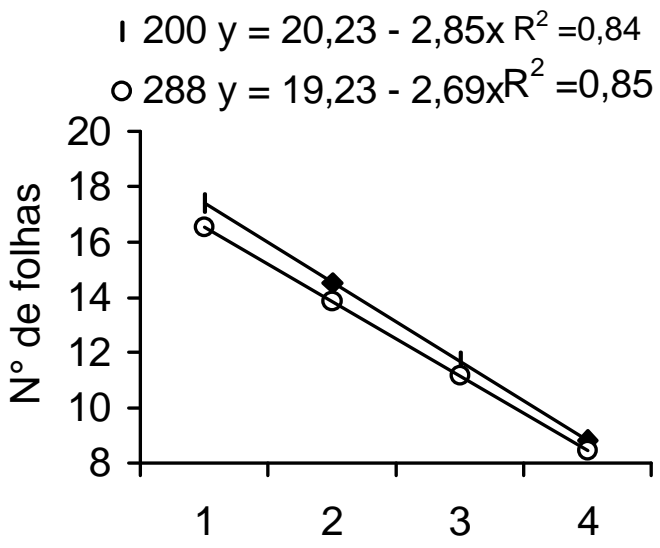

B

Densidade de mudas

FIGURA 1 - Comprimento da parte aérea (A) e número de folhas (B) de rúcula, em função da densidade de mudas em bandejas de 200 e 288 células. UEPG, Ponta Grossa (PR), 2003.

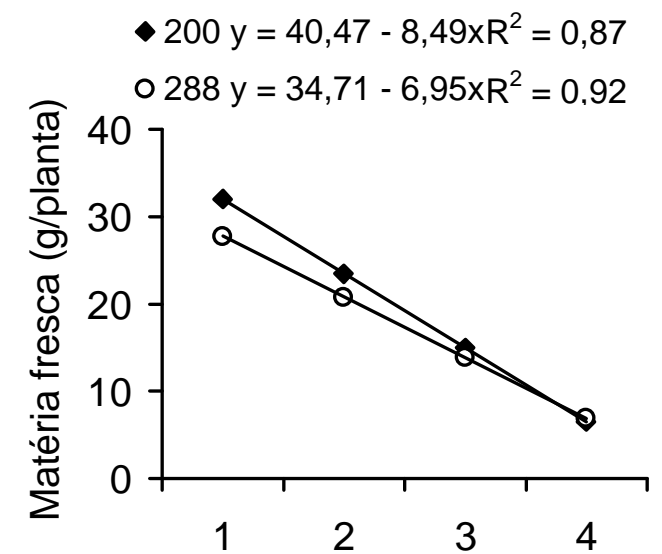

A

Densidade de mudas

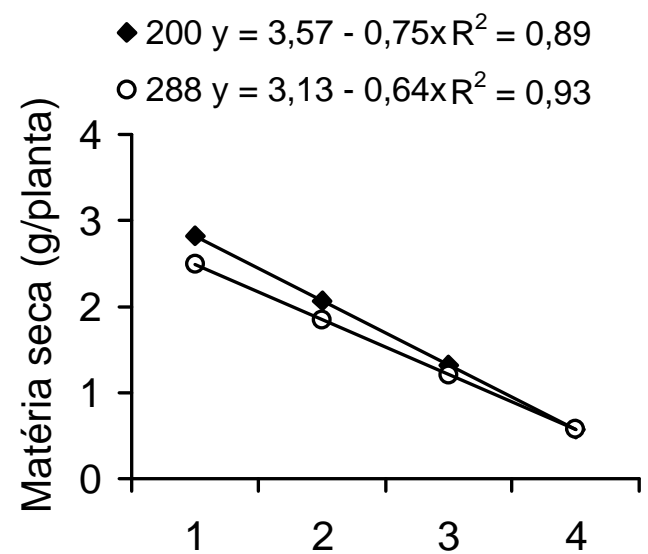

B

\section{Densidade de mudas}

FIGURA 2 - Matéria fresca (A) e seca (B) de rúcula, em função da densidade de mudas em bandejas de 200 e 288 células. UEPG, Ponta Grossa (PR), 2003. 


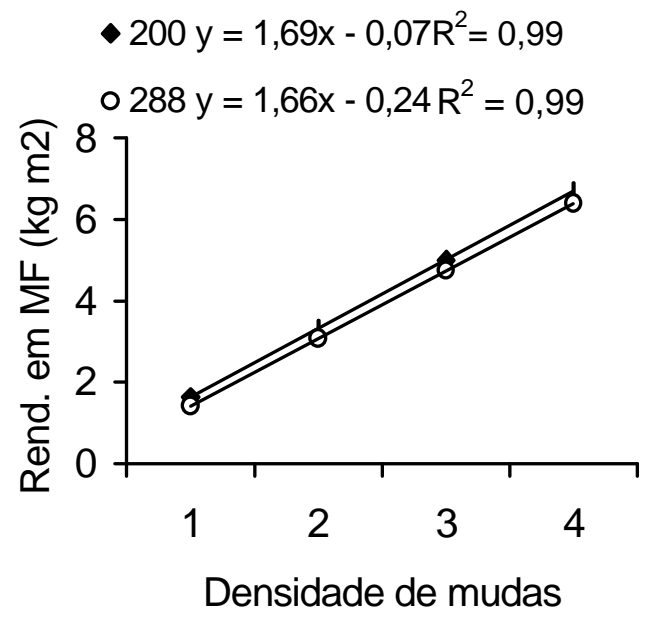

FIGURA 3 - Rendimento por área de matéria fresca, em função da densidade de mudas em bandejas de 200 e 288 células. UEPG, Ponta Grossa (PR), 2003.

\section{CONCLUSÕES}

a) Mudas de rúcula com características superiores foram obtidas na bandeja com 200 células, na densidade de uma muda por célula;

b) $\mathrm{O}$ comportamento diferenciado entre as mudas provenientes de bandejas com 200 e 288 células prevaleceu somente no estádio de mudas. Após o transplante, a densidade foi o fator que afetou a produção final da rúcula;

c) De acordo com o aumento da densidade, ocorreu acréscimo no rendimento de matéria fresca/área, tanto na bandeja de 200 como na de 288 células;

d) A densidade de quatro mudas por célula apresentou-se como recomendação viável para o cultivo da rúcula, independentemente de a bandeja ser de 200 ou 288 células.

\section{REFERÊNCIAS BIBLIOGRÁFICAS}

BARNABÉ, J.; GIORGETTE, J. R.; GOTO, R. Horticultura Brasileira, Brasília, v. 12, n. 1, 1994. Resumo.

BARROS, S. B. M. de. Avaliação de diferentes recipientes na produção de mudas de tomate (Lycopersicon esculentum Mill.) e pepino (Cucumis sativus L.). 1997. 70 f. Dissertação (Mestrado) - Escola Superior de Agricultura Luiz de Queiroz, Universidade de São Paulo, Piracicaba, 1997.
CAMARGO FILHO, W. P.; MAZZEI, A. R. Mercado de verduras: planejamento, estratégia e comercialização. Informações Econômicas, São Paulo, v. 31, n. 3, p. 45-54, 2001.

FILGUEIRA, F. A. R. Novo manual de Olericultura: agrotecnologia moderna na produção e comercialização de hortaliças. Viçosa: UFV, 2000. 402 p.

FISHER, K. J.; BENSON, B. L. K. The effect of nitrogen, volume of media, plant density, and module shape on the growth of asparagus seedlings. Scientia Horticulturae, Amsterdam, v. 24, p. 45-51, 1984.

GUIMARÃES, V. F.; ECHER, M. M.; MINAMI, K. Métodos de produção de mudas, distribuição de matéria seca e produtividade de plantas de beterraba. Horticultura Brasileira, Brasília, v. 20, n. 3, p. 505-509, 2002.

LATIMER, J. G. Container size and shape influence growth and landscape performance of marigold seedling. Hortscience, Alexandria, v. 26, p. 124126, 1991.

MINAMI, K. Produção de mudas de alta qualidade em Horticultura. São Paulo: Agronômica Ceres, 1995. $357 \mathrm{p}$.

MINAMI, K.; TESSARIOLI NETO, J. A cultura da rúcula. Piracicaba: ESALQ, 1998. 19 p. 
MODOLO, V. A.; TESSARIOLI NETO, J. Avaliação do desenvolvimento de mudas de quiabeiro (Abelmoschus esculentus (L.) Moench) em diferentes tipos de bandeja e substrato. In: CONGRESSO BRASILEIRO DE OLERICULTURA, 1998, Petrolina, PE. Anais... Petrolina, PE: [s.n.], 1998. CDROM.
SANTOS, H. S.; ZATARIM, M.; GOTO, R. Influência da densidade e do sistema de semeadura na produção de rúcula. Horticultura Brasileira, Brasília, v. 20, n. 2, 2002. Suplemento 2.

TAVEIRA, J. A. M. Produção de mudas. Curitiba: SENAR, 1996. 86 p. 